\title{
Towards systematic planning of small-scale hydrological intervention-based research
}

\author{
Kharis Erasta Reza Pramana and Maurits Willem Ertsen \\ Water Resources Section, Faculty of Civil Engineering and Geosciences, Delft University of Technology, the Netherlands \\ Correspondence to: Kharis Erasta Reza Pramana (k.e.r.pramana@gmail.com)
}

Received: 31 March 2016 - Published in Hydrol. Earth Syst. Sci. Discuss.: 14 April 2016

Revised: 24 August 2016 - Accepted: 24 August 2016 - Published: 10 October 2016

\begin{abstract}
Many small-scale water development initiatives are accompanied by hydrological research to study either the form of the intervention or its impacts. Humans influence both the development of intervention and research, and thus one needs to take human agency into account. This paper focuses on the effects of human actions in the development of the intervention and its associated hydrological research, as hydrological research is often designed without adequate consideration of how to account for human agency and that these effects have not yet been discussed explicitly in a systematic way. In this paper, we propose a systematic planning for hydrological research, based on evaluating three hydrological research efforts targeting small-scale water development initiatives in Vietnam, Kenya, and Indonesia. The main purpose of the three cases was to understand the functioning of interventions in their hydrological contexts. Aiming for better decision-making on hydrological research in smallscale water intervention initiatives, we propose two analysis steps, including (1) consideration of possible surprises and possible actions and (2) cost-benefit analysis. By performing the two analyses continuously throughout small-scale hydrological intervention-based initiatives, effective hydrological research can be achieved.
\end{abstract}

\section{Introduction}

Small-scale water development initiatives play an important role in supporting sustainable water resources management. Such projects are usually initiated and/or supported by local nongovernmental groups, but also by larger donors such as USAID and others (Van Koppen, 2009; ECSP, 2006; Warner and Abate, 2005). Typical small-scale intervention projects include water harvesting development, improving small-scale irrigation schemes, and small dams for water use or hydropower (Lasage et al., 2008; Ertsen et al., 2005; Falkenmark et al., 2001; Farrington et al., 1999). A basic understanding of the local hydrology is typically required for design, construction, and management of small-scale water interventions.

Many small-scale water intervention initiatives, especially those in the so-called developing countries, are located in data-sparse areas. In 2003, the International Association of Hydrological Sciences (IAHS) initiated the Prediction in Ungauged Basins (PUB) initiative to promote the development and use of improved predictive approaches for a coherent understanding of the hydrological response of ungauged and poorly gauged basins (Sivapalan et al., 2003; Hrachowitz et al., 2013). The three hydrological studies that built our experiences and the approach we developed as discussed in this paper were located in remote areas in Vietnam, Kenya, and Indonesia; all three study areas were originally in ungauged catchments. Our approach for hydrological research was based on investigating dominant hydrological processes through a multimethod approach, in short field campaigns within strict financial constraints (compare with Mul et al., 2009; Hrachowitz et al., 2011). On-site measurements were highly dependent on the support of the local communities. Thus, building and maintaining (informal) networks and relationships were usually essential and required for successful local data collection in all our cases (compared with Mackenzie, 2012).

Our three case studies performed hydrological research within the context of small-scale intervention initiatives; our hydrology was use inspired in terms of understanding and interpretation of local hydrology, including scenario devel- 
opment in human-modified situations, in our case explicit interventions to do so (Srinivasan et al., 2015; Sivapalan et al., 2014; Thompson et al., 2013). Any intervention can be understood in terms of cooperation and negotiation between actors, which together create a process of (re)shaping design, implementation, and use of that intervention (Ertsen and Hut, 2009). In other words, water planning and management are typically co-organized or co-engineered by several actors of different types (Daniell et al., 2010). Our experiences have shown that such co-engineering also shapes the hydrological research itself - and thus principally the science of hydrology as well. As such, we would perceive stakeholder involvement as seeking partnership in the process of (hydrological) change to affect knowledge, attitudes, and behavior of participants in a project's network - rather than researchers simply communicating things to people - (Ertsen, 2002; see also Poolman, 2011, for a more extensive discussion about stakeholder participation in small-scale water initiatives). Motivations for stakeholders' actions within projects - or participation - including acts that may not necessarily be seen as positive by other stakeholders, are a key component for any hydrological project. These motivations may change over time, as we have seen in our Vietnam case study, but there is little recognition of such changes' motivations of individuals over time in the literature. See Cleaver (1999) and Leahy (2008) for some attention to this issue; we return to it below.

Looking at studies of small hydrological research related to interventions - if available at all - another returning issue with stakeholder involvement in hydrological research is its description in terms of theft and vandalism (see Kongo et al., 2010; Mul, 2009; Gomani et al., 2009). When theft and vandalism enter the debate, they seem to be perceived as simple bad luck: they could happen every time and everywhere during a research effort. There is no reason to ignore that people do take away or manipulate equipment in the field we experienced this ourselves - but this does not necessarily make all human interventions leading to disappearing or damaged equipment similar to theft/vandalism. Perhaps people may interfere with measuring equipment out of curiosity, or because they simply do not know what it is. There might be cases of (re)moving equipment when certain agents are against the measurements being taken in the first place, or are against measurements at a certain location - as will be shown below when we discuss how motivations of stakeholders to interfere in our hydrological campaign changed over time, without theft ever being a motivation for action. Whatever the motivations for such involvement, it may result in lower data availability. With data sets being relatively limited anyway in ungauged basins, studies using such limited data have even more difficulty gaining acceptance in the scientific research community (compare with Winsemius, 2009). It is this issue of data availability in relation to stakeholder involvement in small-scale hydrological studies that we discuss in this paper.

When we performed our own hydrological studies, not everything that was about to happen in the three projects was, or probably could be, foreseen. Based on our experiences, in an attempt to compare our experiences and the events afterwards, we traced the social processes relevant for the development of research and intervention in our three cases, looking for possible contextualization, explanations, and patterns. As hydrologists who cannot be separated from the sociohydrological world (Lane, 2014), we searched for a way of conducting small-scale hydrological research in the future that would be informed by our experiences. Can hydrologists make better decisions - in terms of gathering data when planning hydrological research, realizing that people related to and/or involved in the research make decisions on a daily basis that will affect the intervention and hydrological research itself?

Our objective with this paper is to propose a systematic process of planning and performing hydrological research in small-scale water intervention initiatives taking into account the predicted unpredictability (or surprises) of human interventions. We argue that more explicit attention to this topic helps to design more appropriate answers to the challenges faced in hydrological field studies. In particular, we propose two related steps: (1) take into account possible surprises and resulting actions, and (2) using cost-benefit analysis to analyze the need for certain measurements and assess effects of human intervention. In order to be able to design responses during hydrological studies, we argue that human agency from stakeholders - both positive and negative - should be an integral aspect for consideration when designing, performing, and evaluating intervention-based hydrological research. To be clear, our focus on the question whether hydrological research can be made more effective through considering human interventions does not in any case suggest that this is the only relevant question on stakeholder participation in general. It simply means we do not discuss these other questions. Notions of (improving) hydrological research within small-scale projects have been discussed, for example, by Phalla and Paradis (2011), Gomani et al. (2009), and Govardhan Das and Rao (2000), who discuss the importance of hydrological research and local participation in interventions to improve decision-making for such interventions. Involving local communities in hydrological monitoring throughout the world, e.g., in South Africa, Zimbabwe, and India, have shown to be potentially effective for data collection (Kongo et al., 2010; Vincent, 2003; Govardhan Das, 2003; Govardhan Das and Rao, 2000). Merz et al. (2015) study that surprise is apparently a crucial element in flood risk management. To improve flood risk management, one should not neglect surprises, but to take them into account. Similarly, theories and practices of adaptive management have been suggested as potentially beneficial approaches in order to implement an intervention properly (Fabricius and Cundill, 2014; Beratan, 2014; Von Korff et al., 2012). However, a combined focus on both hydrological research design/management and effects of local participation in hydrological research, especially related to the meaning of surprises when doing the 


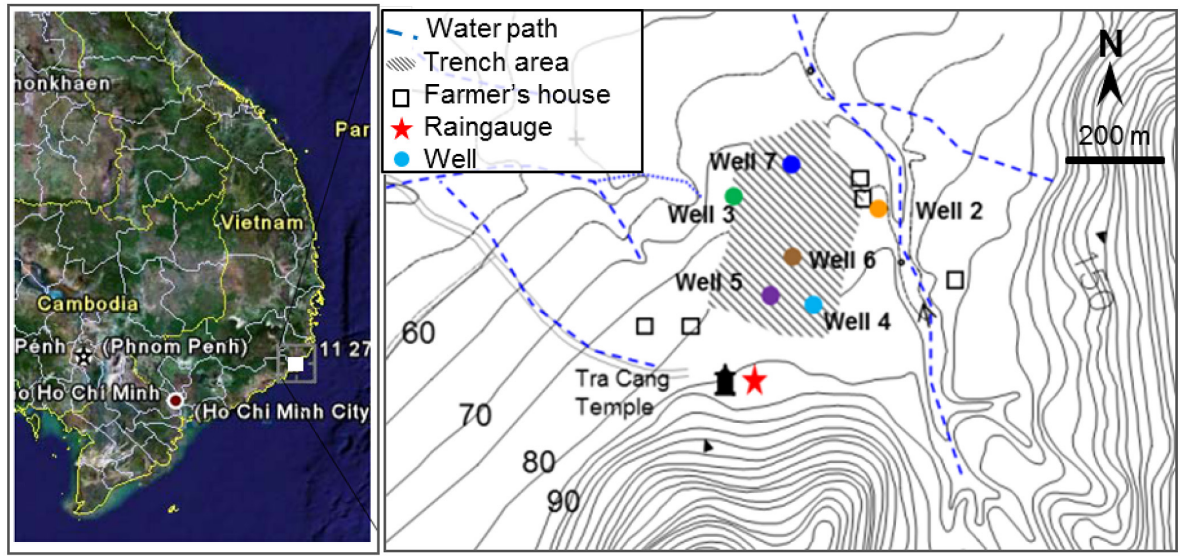

Figure 1. The location of the trenched area, rain gauge, and constructed wells. The study area is the shaded area on the lower map. Source: locally produced map and Google Earth.

field research, remains absent from the literature. Currently, a more systematic overview of issues on planning hydrological research within small-scale water intervention projects is lacking. This paper aims to fill this gap.

We continue this paper with a summary of our three smallscale hydrological research projects and the building blocks of our proposed planning approach. Next, we discuss the Vietnam case in more detail, as this will be the case we build and illustrate our arguments with human agency within the hydrological research, including issues of participation in Vietnam. With the Vietnam experience available, we detail how we propose to include these in planning hydrological research in the context of small-scale water interventions, particularly attempting to account for the likelihood that researcher expectations will be overturned in actual practice i.e., that surprises will occur.

\section{Three small-scale hydrological studies: learning from surprises}

In 2007, contour trenches were dug in a semiarid area in Vietnam (see Fig. 1). A multitechnical approach was used to assess the recharge from water infiltrated in the trenches, using field measurements, isotope techniques, and modeling. In the field, we measured rainfall, water levels in the trenches after events, infiltration, and groundwater in four observation wells in the trench area. In 2009, a complete set of these field measurements was made for a single wet season. Hydrus (2-D/3-D) was used to estimate subsurface parameters of the recharge process. The recharge that was actually created could be beneficial for the short term only, up to a maximum of 2 months. In this case, our multitechnical approach seemed to have provided an adequate understanding of the mechanism of local recharge. Below, we will describe in more detail the process of the research activities, but first we provide some background on our other two cases.
In 2002, contour trenching was initiated to trigger reforestation in a semiarid area in Amboseli, Kenya (see Fig. 2; it was actually the experience in this region that created conditions for the Vietnam project). To study the effects of the trenches, fieldwork was performed in September 2010, consisting of rainfall measurements, soil moisture measurements, and soil samplings. The aim was to assess the impacts of contour trenching on vegetation growth, soil moisture availability, and sedimentation distribution in the trench area. We could only perform a very minor part of these measurements, as much of our on-site equipment disappeared from the site. To understand erosion and sedimentation in the trench area, we could take soil samples with which cesium analysis was performed. Local and external sediment were found in the trench area. Remote sensing analysis was conducted to investigate the differences between situations with and without contour trenches. Results showed that the signal of high greenness index in the trench area was most likely due to the wet season, and not specifically because of the trenches per se.

In 2010 , the potential of micro-hydro power plants was investigated in the Maluku province, Indonesia (see Fig. 3). The study combined a digital elevation model (DEM, from the space shuttle Endeavor), rainfall, and discharge measurements. Using DEM analysis, a river map with high elevation differences was determined. Discharge measurement data of 1 year were used to determine the runoff per unit area. It was concluded that the Maluku Islands have small potential for micro-hydro power plants, with estimation ranges from 6 to $40 \mathrm{~kW}$. This research project went very smoothly, with local stakeholders only protesting once our studies suggested that the potential for micro-hydro on the study area was only marginal.

Concerning the hydrological/technical aspects of the three case studies, we conducted different measurement techniques depending on the research objectives. We experienced 


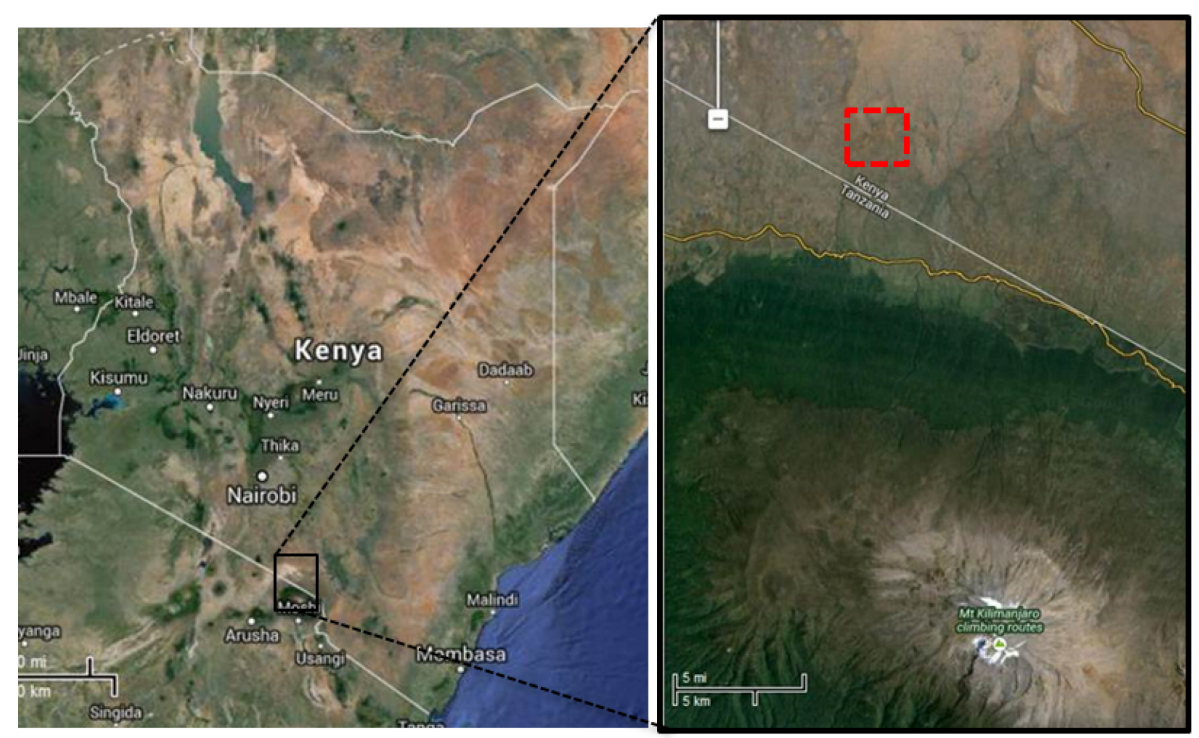

Figure 2. Location of studied contour trenching in Amboseli, Kenya (red dashed line). Source: Google Maps.

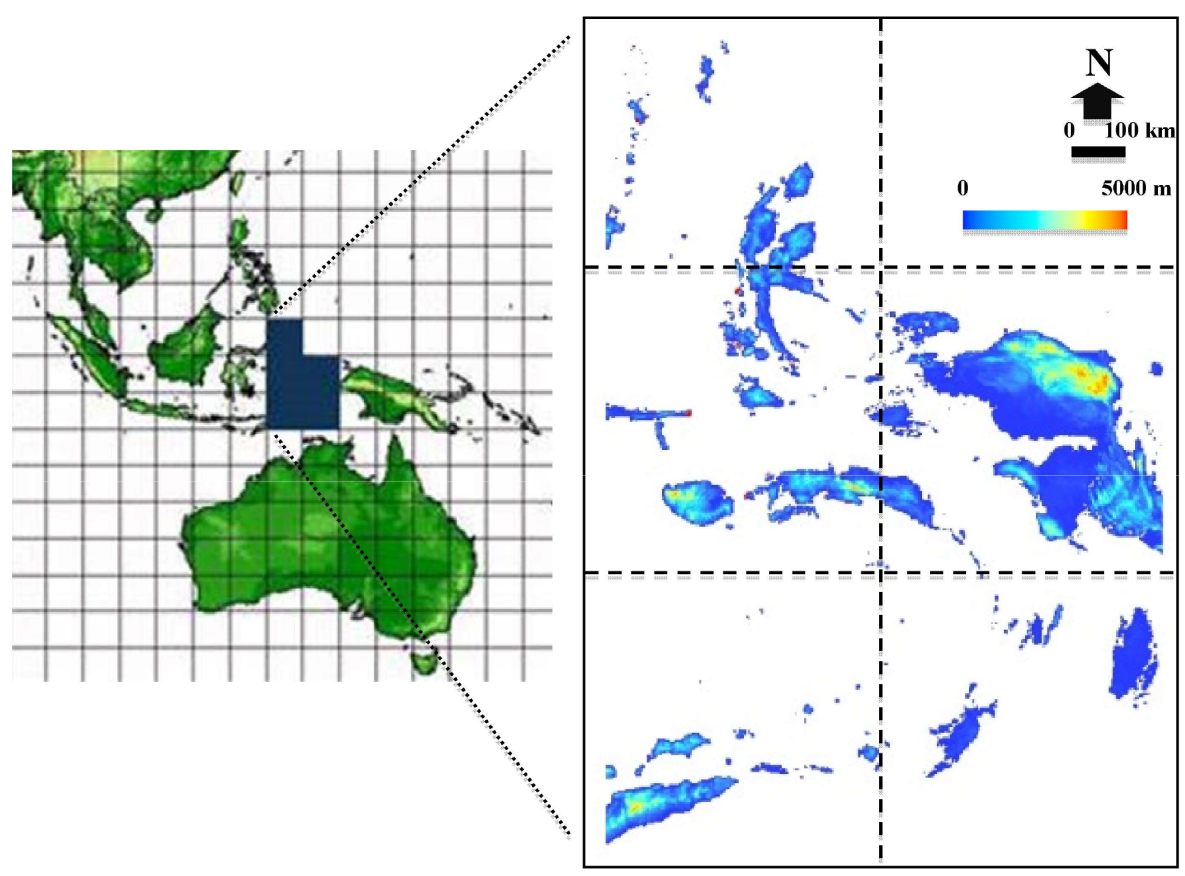

Figure 3. The result of merged and processed DEM tiles on the Maluku Islands.

that the development of intervention and hydrological research changed over time due to actions of local stakeholders. In each of the interventions and research in Vietnam, Kenya, and Indonesia, local stakeholders of different kinds were engaged. To better understand human actions in smallscale water intervention-based research, we looked into the different actions we could collect and considered those as data for further discussion on the social aspects; see Tables $1-3$. For our three cases (see Table 4 for the timeframes), we drafted the human actions in intervention and hydrological research. We focus on the Vietnam case since it contains more events compared to the Kenya and Indonesia cases. In order to gain insight on human actions in hydrological research, a timeframe of the social context was made for all three case studies. In our efforts to conceptualize human agency in intervention and research, we looked at existing theories on community participation (several of which were quoted in the introduction). In an early discussion - which we 
Table 1. (a) Vietnam case: hydrological research; (b) Vietnam case: intervention.

\begin{tabular}{|c|c|c|c|c|}
\hline $\begin{array}{l}\text { Procedure (the official way of } \\
\text { conducting hydrological } \\
\text { research) }\end{array}$ & $\begin{array}{l}\text { Event or observation (an } \\
\text { indisputable happening) }\end{array}$ & $\begin{array}{l}\text { Action (the process before } \\
\text { an event) }\end{array}$ & $\begin{array}{l}\text { Interpretation (giving a } \\
\text { meaning of the event and/or } \\
\text { action to research) }\end{array}$ & Period \\
\hline \multirow[t]{3}{*}{ Install two rain gauges } & Intermittent rainfall data & - & - & October 2007-March 2011 \\
\hline & Clogged rain gauges (no. 1) & $\begin{array}{l}\text { Need of checks and } \\
\text { maintenance }\end{array}$ & Loss of rainfall data series & October 2008 \\
\hline & $\begin{array}{l}\text { Logger failed to record events } \\
\text { (no. 2) }\end{array}$ & $\begin{array}{l}\text { Tried to retrieved data from } \\
\text { manufacture company and } \\
\text { manual measurement }\end{array}$ & Loss of rainfall data series & December 2009-March 2011 \\
\hline $\begin{array}{l}\text { Install access tubes for soil } \\
\text { moisture measurements }\end{array}$ & Loss of access tubes (no. 3) & $\begin{array}{l}\text { Substituted with new access } \\
\text { tubes }\end{array}$ & $\begin{array}{l}\text { Loss of soil moisture data se- } \\
\text { ries, extra costs for new tubes }\end{array}$ & September 2008-March 2011 \\
\hline $\begin{array}{l}\text { Check infiltration at the } \\
\text { bottom of the trench }\end{array}$ & - & - & - & September 2009-November 2009 \\
\hline $\begin{array}{l}\text { Measure soil porosity } \\
\text { and bulk density }\end{array}$ & - & - & - & October 2007-June 2009 \\
\hline Measure infiltration capacity & - & - & - & October 2007 and April 2009 \\
\hline $\begin{array}{l}\text { Measure surface water level in } \\
\text { the trenches during wet season }\end{array}$ & - & - & - & October 2007-November 2009 \\
\hline \multirow[t]{3}{*}{ Construct observation wells } & Loss of divers (no. 4) & Perform manual measurement & $\begin{array}{l}\text { Loss in groundwater level data } \\
\text { series }\end{array}$ & December 2007 \\
\hline & $\begin{array}{l}\text { Improper screen instalment for } \\
\text { isotope sampling (no. 5) }\end{array}$ & Nothing & $\begin{array}{l}\text { Possible misinterpretation of } \\
\text { isotope signal }\end{array}$ & October 2007 and April 2009 \\
\hline & $\begin{array}{l}\text { Construction before interven- } \\
\text { tion (no. 6) }\end{array}$ & $\begin{array}{l}\text { Extra costs for constructing } \\
\text { new wells }\end{array}$ & $\begin{array}{l}\text { A shift in location of interven- } \\
\text { tion requires more measure- } \\
\text { ments, thus more cost }\end{array}$ & October 2007-April 2009 \\
\hline \multicolumn{5}{|l|}{ (b) } \\
\hline $\begin{array}{l}\text { Procedure (the common way } \\
\text { of intervention) }\end{array}$ & $\begin{array}{l}\text { Event or observation (an indis- } \\
\text { putable happening) }\end{array}$ & $\begin{array}{l}\text { Action (the process before an } \\
\text { event) }\end{array}$ & $\begin{array}{l}\text { Interpretation (giving a } \\
\text { meaning of the event and/or } \\
\text { action to intervention) }\end{array}$ & Period \\
\hline $\begin{array}{l}\text { Introducing the concept of } \\
\text { intervention to local } \\
\text { authority and community }\end{array}$ & Meetings & $\begin{array}{l}\text { Presentations and discussions } \\
\text { to obtain support }\end{array}$ & $\begin{array}{l}\text { Needed an agreement from } \\
\text { local community }\end{array}$ & May 2006-September 2007 \\
\hline \multirow[t]{6}{*}{$\begin{array}{l}\text { Constructing contour trenches } \\
\text { (no. 6A) }\end{array}$} & $\begin{array}{l}\text { A monks' organization pro- } \\
\text { vided their land in a size of } 12 \\
\text { ha for intervention }\end{array}$ & $\begin{array}{l}\text { Larger trenches were con- } \\
\text { structed on } 8 \text { ha area }\end{array}$ & $\begin{array}{l}\text { Needed an agreement on } \\
\text { someone's land to be } \\
\text { interfered }\end{array}$ & October 2007 \\
\hline & $\begin{array}{l}\text { After large contour trenching, } \\
\text { the monks' organization re- } \\
\text { fused to continue construction } \\
\text { on their remaining land }\end{array}$ & $\begin{array}{l}\text { Meetings and discussions } \\
\text { to convince the intervention } \\
\text { would be beneficial for the } \\
\text { community }\end{array}$ & $\begin{array}{l}\text { Although the monks gave } \\
\text { permission for large contour } \\
\text { trenching, they did not like the } \\
\text { design }\end{array}$ & November 2007-March 2008 \\
\hline & $\begin{array}{l}\text { The initiator approached other } \\
\text { land owners }\end{array}$ & $\begin{array}{l}\text { The initiator offered a smaller } \\
\text { contour trench design }\end{array}$ & Negotiated on the design & March 2008 \\
\hline & $\begin{array}{l}\text { A local farmer accepted the } \\
\text { smaller trench design }\end{array}$ & $\begin{array}{l}\text { Construction of smaller } \\
\text { contour trenches on } 1 \text { ha area }\end{array}$ & $\begin{array}{l}\text { The smaller design was } \\
\text { tested }\end{array}$ & April 2008-May 2008 \\
\hline & $\begin{array}{l}\text { Other local farmers requested } \\
\text { smaller contour trenching }\end{array}$ & $\begin{array}{l}\text { Construction of smaller } \\
\text { contour trenches on other } \\
\text { farmers' land (10 ha) }\end{array}$ & $\begin{array}{l}\text { The smaller design was } \\
\text { preferred }\end{array}$ & June 2008-August 2008 \\
\hline & $\begin{array}{l}\text { The monks' organization also } \\
\text { provided their remaining land } \\
\text { for smaller contour trenching }\end{array}$ & $\begin{array}{l}\text { Construction of smaller } \\
\text { contour trenches on the } \\
\text { remaining } 4 \text { ha area }\end{array}$ & $\begin{array}{l}\text { Overall in this particular } \\
\text { local community, a larger } \\
\text { design was not accepted }\end{array}$ & June 2008-August 2008 \\
\hline
\end{tabular}

found very useful for our case studies - Arnstein (1969) introduced the ladder of participation for urban development, with the scale ranging from nonparticipation to being able to make decision (citizen empowerment). The scale influenced other fields and was further developed, for example, by Choguill (1996). Her ladder of participation was based on the scale of willingness of governments in community projects. One recent participatory spectrum is IAP2 (2007), where along the spectrum, the impact of public participation increases. Another participation framework during intervention phases was proposed by Srinivasan (1990), explicitly aiming at training trainers in participatory techniques. We 
Table 2. (a) Kenya case: hydrological research; (b) Kenya case: intervention.

\begin{tabular}{|c|c|c|c|c|}
\hline (a) & & & & \\
\hline $\begin{array}{l}\text { Procedure (the official way } \\
\text { of conducting hydrological } \\
\text { research) }\end{array}$ & $\begin{array}{l}\text { Event or observation (an } \\
\text { indisputable happening) }\end{array}$ & $\begin{array}{l}\text { Action (the process } \\
\text { before an event) }\end{array}$ & $\begin{array}{l}\text { Interpretation (giving a } \\
\text { meaning or impact of } \\
\text { the event to research) }\end{array}$ & Period \\
\hline \multirow[t]{2}{*}{ Install two rain gauges } & $\begin{array}{l}\text { One rain gauge was damaged } \\
\text { by elephants and thus removed } \\
\text { by local people (no. } 7 \text { ) }\end{array}$ & $\begin{array}{l}\text { Information came very late, } \\
\text { thus arrangement for reset up } \\
\text { of the rain gauge could not be } \\
\text { performed }\end{array}$ & Loss of rainfall data series & September 2010-March 2012 \\
\hline & $\begin{array}{l}\text { One logger failed to record } \\
\text { events (no. 8) }\end{array}$ & $\begin{array}{l}\text { Tried to retrieve data without } \\
\text { success }\end{array}$ & Loss of rainfall data series & September 2010-March 2012 \\
\hline \multirow[t]{2}{*}{$\begin{array}{l}\text { Soil moisture measurements to } \\
\text { be conducted by a local person }\end{array}$} & $\begin{array}{l}\text { A long negotiation to start } \\
\text { measurement was not success- } \\
\text { ful (no. 9) }\end{array}$ & $\begin{array}{l}\text { Established new connection } \\
\text { with other local people was } \\
\text { not successful too }\end{array}$ & $\begin{array}{l}\text { Loss of soil moisture } \\
\text { data series }\end{array}$ & September 2010-Mach 2013 \\
\hline & Loss of access tubes (no. 9A) & Installed two remaining tubes & $\begin{array}{l}\text { Loss of soil moisture } \\
\text { data series }\end{array}$ & September 2010-March 2012 \\
\hline $\begin{array}{l}\text { Used TRMM and NDVI } \\
\text { analysis }\end{array}$ & - & - & - & January 2011-March 2011 \\
\hline $\begin{array}{l}\text { Measure soil porosity and } \\
\text { bulk density }\end{array}$ & - & - & - & September 2010 \\
\hline $\begin{array}{l}\text { Soil sampling for } \\
\text { cesium analysis }\end{array}$ & - & - & - & September 2010 \\
\hline \multicolumn{5}{|l|}{ (b) } \\
\hline $\begin{array}{l}\text { Procedure (the } \\
\text { common way of } \\
\text { intervention) }\end{array}$ & $\begin{array}{l}\text { Event or observation } \\
\text { (an indisputable } \\
\text { happening) }\end{array}$ & $\begin{array}{l}\text { Action (the process } \\
\text { before an event) }\end{array}$ & $\begin{array}{l}\text { Interpretation (giving } \\
\text { a meaning of the event } \\
\text { and/or action to } \\
\text { intervention) }\end{array}$ & Period \\
\hline $\begin{array}{l}\text { Introducing the concept of } \\
\text { intervention to local authority } \\
\text { and community }\end{array}$ & Meetings & $\begin{array}{l}\text { Convincing local people with } \\
\text { success }\end{array}$ & $\begin{array}{l}\text { Local people accepted } \\
\text { the design }\end{array}$ & $2001-2002$ \\
\hline Constructing contour trenches & $\begin{array}{l}\text { The majority of Maasai } \\
\text { supported contour trenches }\end{array}$ & $\begin{array}{l}\text { Trenches were first } \\
\text { constructed in smaller } \\
\text { dimension and furthermore } \\
\text { in larger ones }\end{array}$ & $\begin{array}{l}\text { Easy to implement different } \\
\text { dimension of contour trench- } \\
\text { ing in this particular area }\end{array}$ & $2002-2006$ \\
\hline $\begin{array}{l}\text { After construction of large } \\
\text { contour trenches }\end{array}$ & - & - & - & 2002-present \\
\hline
\end{tabular}

found this last approach useful in analyzing our case studies, as the community participation scale from Srinivasan (1990) allows for differentiating attitudes towards change, by sorting them along a scale showing varying degrees of resistance or openness. We use the scale below to identify attitudes towards hydrological research, and are also able to show these attitudes change over time. In itself, the realization that attitudes can change over the course of a project strongly suggests that stakeholder attitudes and considerations need to be considered in projects. Again, in this paper, we use this basic analysis on community participation including what went differently than expected to discuss how in the future such developments could be anticipated upon when planning hydrological research in the narrow meaning of planning equipment and measurements.

After identifying the participation of local people in intervention and research, we developed research budget scenarios for the three cases, where we defined effectiveness in terms of process understanding and important model input. Thinking in scenarios for hydrological fieldwork instead of one single approach allowed for making decisions based on expected implications of events on the hydrological results, with the aim to minimize the costs of improvisation. In the procedure, we first evaluated the technical approaches per case study in terms of performance (Blume et al., 2008), defined as the effectiveness of measurements in understanding hydrological processes. We used cost-benefit analysis (Sassone, 1978) in research scenarios that were developed based on the Delphi method (Linstone and Turoff, 1975). A range of budgets were given to hydrological scholars as examples to illustrate the expenditures, with each scenario specifying a budget, the measurements that can be conducted within that budget, and the dominant hydrological processes studied. We asked those scholars their assessment of the added value of higher budgets for gaining understanding of the local hydrological situation of the case area. In changing the budgets, we could explore changes in and differences between probable field campaigns, especially in gaining better understanding of dominant mechanisms of the intervention. Our approach builds on the budgets of scenarios, as budgets in small-scale 
Table 3. (a) Indonesia case: hydrological research; (b) Indonesia case: intervention.

\begin{tabular}{|c|c|c|c|c|}
\hline \multicolumn{5}{|l|}{ (a) } \\
\hline $\begin{array}{l}\text { Procedure (the official way } \\
\text { of conducting hydrological re- } \\
\text { search) }\end{array}$ & $\begin{array}{l}\text { Event or observation (an } \\
\text { indisputable happening) }\end{array}$ & $\begin{array}{l}\text { Action (the process } \\
\text { before an event) }\end{array}$ & $\begin{array}{l}\text { Interpretation (giving a } \\
\text { meaning or impact of the } \\
\text { event to research) }\end{array}$ & Period \\
\hline Install two rain gauges & $\begin{array}{l}\text { One logger failed to record } \\
\text { events (no. 10) }\end{array}$ & Only counted on one logger & Loss of rainfall data series & July 2010-July 2011 \\
\hline Install two divers & $\begin{array}{l}\text { One logger failed to record } \\
\text { events (no. 11) }\end{array}$ & Only count on one diver & Loss of water level data series & July 2010-July 2011 \\
\hline $\begin{array}{l}\text { Measure discharge using dilu- } \\
\text { tion method and velocity area }\end{array}$ & - & - & - & February 2011-March 2011 \\
\hline Used DEM analysis & - & - & - & April 2011-June 2011 \\
\hline \multicolumn{5}{|l|}{ (b) } \\
\hline $\begin{array}{l}\text { Procedure (the common way } \\
\text { of intervention) }\end{array}$ & $\begin{array}{l}\text { Event or observation (an indis- } \\
\text { putable happening) }\end{array}$ & $\begin{array}{l}\text { Action (the process before an } \\
\text { event) }\end{array}$ & $\begin{array}{l}\text { Interpretation (giving a mean- } \\
\text { ing of the event and/or action } \\
\text { to intervention) }\end{array}$ & Period \\
\hline $\begin{array}{l}\text { Proposed intervention to local } \\
\text { authority and community }\end{array}$ & $\begin{array}{l}\text { Meetings, permit issue, esti- } \\
\text { mation of micro-hydro budget } \\
\text { and research on its potential }\end{array}$ & - & - & March 2010-June 2011 \\
\hline $\begin{array}{l}\text { Design suitable micro-hydro } \\
\text { installation }\end{array}$ & $\begin{array}{l}\text { Two plans were agreed; first } \\
\text { an installation of about } 80 \mathrm{~kW} \\
\text { and second small kW was esti- } \\
\text { mated after the research }\end{array}$ & $\begin{array}{l}\text { Search for extra funding to } \\
\text { meet the construction cost }\end{array}$ & $\begin{array}{l}\text { A decision had to be made } \\
\text { based on the availability of } \\
\text { funding }\end{array}$ & July 2010-January 2012 \\
\hline Pilot result & $\begin{array}{l}\text { Research result suggests lit- } \\
\text { tle potential for micro-hydro } \\
\text { installation in a village, but } \\
\text { funding was still not enough }\end{array}$ & $\begin{array}{l}\text { Constructed micro-hydro } \\
\text { model for a local university }\end{array}$ & $\begin{array}{l}\text { The final intervention shifted } \\
\text { from a pilot to a model }\end{array}$ & September 2012-September 2013 \\
\hline
\end{tabular}

Table 4. Time periods of three hydrological intervention-based research projects.

\begin{tabular}{l|ll|ll}
\hline \multirow{2}{*}{ Case study } & \multicolumn{2}{|c|}{ Intervention } & \multicolumn{2}{c}{ Hydrological research } \\
\cline { 2 - 5 } & Start & End & Start & End \\
\hline Vietnam & October 2007 & September 2008 & October 2007 & March 2011 \\
Kenya & 2002 & 2003 & September 2010 & March 2012 \\
Indonesia & September 2012 & September 2013 & July 2010 & October 2011 \\
\hline
\end{tabular}

projects are usually constrained, but everyone still expects good results. Thinking in terms of costs and benefits also allowed making the issues of planning/considering additional measurement activities as concrete as possible for the hydrological researchers we involved in our study.

Based on the results of considering stakeholder participation and cost-benefit scenarios, we were able to develop suggestions how hydrological researchers can include considerations on human agency when planning and performing hydrological field research.

\section{Vietnam case: contour trenches for artificial recharge in the Ninh Thuan province}

Contour trenching is a water harvesting technique implemented to increase water availability in semiarid and arid region. A study on trenches in Chile by Verbist et al. (2009) suggested that only few cases did quantify the (positive) ef- fect of runoff water harvesting techniques on water retention. One older study, Doty (1972), found that almost no change in soil water between areas with and without trenches. In the Vietnam study, we investigated recharge processes of contour trenching, in a study area located in the Phuoc Nam commune, in Ninh Phuoc district (latitude $11^{\circ} 27^{\prime} 46.06^{\prime \prime}$ and longitude $108^{\circ} 55^{\prime} 44.39^{\prime \prime} \mathrm{E}$ ). The landscape is a foothill with an average slope of about $3.5 \%$. It is dominated by mountainous granite and downhill valley with mix of loamy sand, weathered granite, residual soils, and alluvial deposits. The climate is dominated by tropical monsoons. Generally, the wet season with heavy rainfall events occurs from September to December. From April to May there are occasional light rainfall events. The dry seasons are from January to April and from June to August. The average rainfall is $810 \mathrm{~mm} \mathrm{yr}^{-1}$. The landscape appeared as bare soil with erosion gullies, with some parts covered by cacti and grasses. Contour trenching using $4 \mathrm{~m}$ wide and $1 \mathrm{~m}$ deep trenches was planned for an area of 97 ha. Ultimately, however, only 22 ha were trenched 
with a combination of $4 \mathrm{~m}$ wide, $1 \mathrm{~m}$ deep and $1 \mathrm{~m}$ wide, $0.8 \mathrm{~m}$ deep trenches. The hydrological research itself focused on an area of about 8 ha.

As already referred to briefly, we conducted a multimethod approach during a single wet year in 2009. Only during one 6-month period (June to November 2009) data of rainfall, water levels, and groundwater levels were simultaneously available. On 11 October 2007, before the construction of contour trenches, we installed two rain gauges (Casella tipping buckets, $0.2 \mathrm{~mm}$, with a $\mathrm{HOBO}$ data logger). Infiltrated ponding water in the trenches was monitored daily after rainfall events. The surface water was measured using a stick and two measuring scales in the trenches. The subsurface (geology and soil) survey was partially conducted three times, in October 2007, March 2008, and June 2009. In October 2007, we performed inverse auger tests (Porchet and Laferrere, 1935) to obtain hydraulic conductivity values at six locations spanning an uphill to downhill transect through the proposed trench area. In March 2008, we drilled 3 m holes at eight locations for additional lithology investigations. We also took four soil samples at the trench plots and analyzed those using wet and dry methods at the laboratory of UNESCO-IHE Delft. In October 2007, we constructed three observation wells (wells 1,2, and 3) at the upstream and middle part of the planned project area. We measured the groundwater level with divers (Schlumberger Water Services, Delft, The Netherlands). Because of the loss of two divers in two different observation wells, after February 2008 we measured groundwater level manually on a 3- to 4-day basis. Moreover, we performed an isotope study; as such studies on recharge are known to allow improved understanding of catchment dynamics (Rodgers et al., 2005; McGuire and McDonnell, 2007). From September 2009 to November 2009, 72 water samples were collected in $2 \mathrm{~mL}$ vials. ${ }^{18} \mathrm{O}$ variation of rainfall, surface water, and groundwater were analyzed at the Isotope Laboratory of Delft University of Technology. Field measurements and isotope results were then used in Hydrus (2-D/3-D) modeling (Šimůnek et al., 2008).

The combination of field measurements, the isotope technique, and modeling over a 6-month period enabled us to understand the recharge process in contour trenching plots in Vietnam. We concluded that artificial recharge took place in the trench area. In the long term, we are confident that infiltration in the trenches will increase the groundwater levels at the sites. Rapid groundwater level increase during the wet season is followed by gradual drawdown during the dry season. For the time being, the trenches seem to benefit shortterm subsurface storage.

In an attempt to look at human actions towards intervention and hydrological research more systematically, we started by identifying the process of participative actions from local people using the scale from Srinivasan (1990); see Fig. 4. Table $1 \mathrm{~b}$ provides the detailed results in terms of timing and type of human actions during our intervention processes. The Vietnamese intervention could only be con- structed after many negotiations between the initiator and the end users. Such a decision could change the final location of the intervention, which in turn affected directly the hydrological field research. In Vietnam, intervention design and location were determined by the local people, who had the power to choose their preference of intervention and decided whether it could be implemented on their land or not. At the beginning of the Vietnam project, none of the landowners agreed with the intervention, especially because they had not yet seen a successful example in their particular area. After negotiations, a monk organization was willing to provide their land as an example case (no. 6A). Hydrological equipment was installed to study the effect of the trenches. After the large trenches were constructed, the monk organization did not like the design. Their rejection of the large trenches enforced the intervention team to reconsider the trench dimensions. Thus, the team came up with a smaller design of contour trenches. Despite the smaller design, the monk organization still refused to continue implementing the new design on its remaining land. Consequently, the project introduced the smaller design to other farmers and one farmer accepted it. The smaller trenches were then implemented in one farmers' area, and additional hydrological equipment was installed. The acceptance of the smaller design by other farmers continued. Farmers living nearby requested also the small trenches to be constructed on their land. After the monks' organization saw the results at several farmers' land, the monk organization eventually requested the initiator to construct small trenches on their remaining land. The decision of local people who wanted to have contour trenches occurred after seeing an example of a smaller design.

In terms of the scale of participation of the above community, we can observe several steps along the ladder (as depicted in Fig. 4):

- 0 to 6: among many landowners, only a monk organization was willing "to try some actions" on their land.

- 6 to 3: the monk organization was skeptical and "have doubts" if they continue implementing the trenches, even with a smaller design.

- 3 to 6: a farmer was willing "to try some actions" on his land.

- 6 to 7: from one farmer with smaller trench design, he advocated change so that the acceptance of the smaller design continued in this particular area.

The engagement of the local community in the hydrological field research was analyzed similarly, since it was part of the intervention itself. We found this potential to measure attitude even more interesting because our results suggest that these attitudes of stakeholders change over time in the hydrological research itself as well.

In general, we find different processes of involvement and different human actions related to the three hydrological re- 


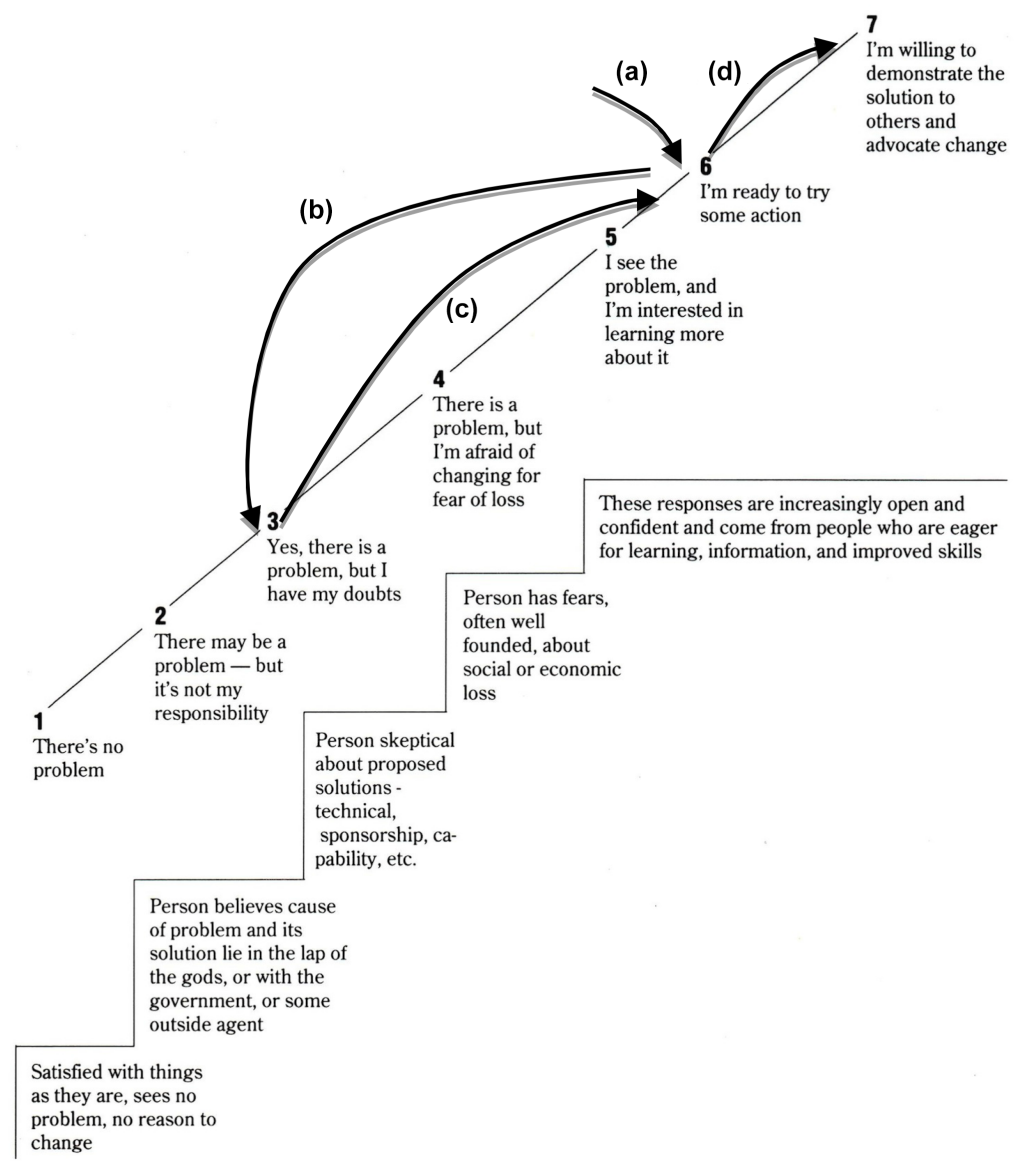

Figure 4. The implemented intervention based on the scale of community participation of Srinivasan (1990).

search projects (see Table 1a, on events labeled with "no."). For example, both in Vietnam and Kenya, access tubes (no. 3, no. 9A) were taken away. In Vietnam, the divers were taken away as well (no. 4). Next to human agency affecting the hydrological research, other events affected the research activities. In Vietnam, one rain gauge clogged (no. 1) because of fine sands from strong winds, and the screen of the observation wells (no. 5) proved to be not suitable for local conditions (in Kenya, one rain gauge was actually damaged by elephants, and afterwards removed by local people (no. 7)). Obviously, these events could possibly have been avoided. Rain gauges could have been checked and maintained on a regular basis, especially when realizing that local conditions and climate might affect the measurement. However, there were also problems that probably could not have been avoided, especially technical failures of data loggers (no. 2, no. 8, no. 10, no. 11) from tipping buckets and divers.

Within the context where intervention was done simultaneously with hydrological research - the Vietnam case (no. 6) - the actual form of the final intervention was decided upon within several rounds of discussions between project team and local communities. Agreement was obtained through a negotiation process. The actual form of the hydrological research was heavily dependent upon knowing the definitive location of the intervention. While the decision process took place, measurements were conducted in the vicinity of the possible locations of the intervention. On-site measurements had to be re-evaluated from time to time due to changes of intervention locations. The intervention period and financial support for research were both limited and limiting as well. Most likely, in conditions of simultaneous intervention and research, changes required adjustments to a new setup, which often means increasing financial expenditure for measurements. Therefore, any decision to start either intervention or hydrological research needs careful thought.

The Srinivasan scale allows for analyzing the changes in attitudes and possible actions concerning an intervention over time. How motivation for action is always directly linked to an attitude towards the intervention remains an open question. An example is the Vietnam case, where access tubes and divers were taken away. Possible reasons may have been that someone rejected the project, did not want 
any intervention to be constructed on the land, had negative impressions of the intervention, or was not satisfied with the project's offer. On the other hand, the attractiveness of the device itself and/or curiosity could make people eager to have such devices. Therefore, the resulting human action to remove the device may not have been a rejection of the project at all, but just a desire to own a device with a unique appearance.

\section{Human actions as surprises in intervention development and hydrological research}

Our own experience showed that human actions influenced both the development of intervention and hydrological research. We claim that such events due to human actions could have been anticipated - or even (partially) avoided, by us as well - but usually are treated as unforeseen side effects or surprises when they happen - as we did ourselves. For dealing with such surprises, we have found the frameworks, as developed by the RAND cooperation on how to be prepared when facing surprises in planning, extremely useful. Dewar (2002) (see also Dewar et al., 1993) discusses such surprises and provides a tool for improving the adaptability and robustness of existing plans by making assumption-based planning (ABP). With $\mathrm{ABP}$, one would double check the planners' awareness of uncertainties associated to any plan, including assumptions that might have been overlooked.

Baiocchi and Fox (2013) suggest six key issues to be prepared for and respond to surprises: (1) learn from experience: attract and retain the most experienced people; (2) address the negative effects of surprise; (3) assess the level of chaos in the work environment; (4) prepare for "third-party surprises"; (5) focus on building a network of trusted colleagues; and (6) conduct regular future-planning exercises. Their recommendations confirm our ideas: planning for surprise requires proper understanding of small interventions within their hydrological context and incorporating interdisciplinary knowledge, learning, and local participation (see Karjalainen et al., 2013; Rodela et al., 2012; Reed et al., 2010).

Despite this potential of looking at uncertainty in planning of small-scale hydrological research related to human actions, there is still a long way to go. The above-mentioned bias towards not publishing small-scale studies not only may limit understanding of the hydrology of small-scale water systems but it also prevents understanding the nature and performance of the small-scale studies in relation to the intervention itself. Our attempt to operationalize the concept of surprise-based planning in hydrological research, we focused on cost-benefit analysis.

We all know that research budgets for small-scale interventions are usually constrained (e.g., Phalla and Paradis, 2011). In terms of time constraints, a very useful example of how to optimize short-term data is offered by Hagen and Evju (2013). To understand a certain water intervention, ide- ally a hydrological researcher would prefer measurements being conducted at many locations, for a long time and with high frequency. However, within that general preference and given financial constraints, much remains to be chosen by the researcher (Hamilton, 2007; Soulsby et al., 2008). This suggests that different researchers would select different actions and measurement techniques, even when performing a similar type of hydrological research. As such, options can be studied in terms of costs and benefits. What to do with limited budgets and the possible gains that can be made with certain (additional) measurements or activities at a cost encourages (forces) hydrological researchers to take into account how to deal with possibly costly surprises in preparing and implementing field research. We tested this scenario approach with a group of experts, offering three scenarios. Scenario 1 was approximately at the lowest budget, which was estimated by considering the experiences gained by the author. As we already knew how the research went, we set the lowest cost scenario by eliminating the measurements that failed or were not used in the analysis. This scenario combined at least a desk study with field measurement data. In addition, this scenario was a theoretical baseline for a good understanding of the intervention.

Scenarios 2 and 3 covered a longer research period. Extension of measurement and performing other methods were proposed. There were several options related to parameters that were selected and added, with various spatial and temporal combinations. The options we have to make to confirm certain underlying dominant hydrological processes due to an intervention were the following:

A: extension of the measurement period;

B: additional samplings;

C: additional measurement devices;

D: additional analysis.

Options $\mathrm{C}$ and $\mathrm{D}$ are connected since having another type of measurement might use the same or require a new (commercial) software program or service.

Scenario 2 was set with a budget increase of about $20 \%$. We preferred to use this extra budget for the extension of the measurement period and more samplings.

Scenario 3 was set with a budget increase of approximately $80 \%$. It implies a condition of an expansion of scenario 2 combined with much more room for additional parameters in the field campaign.

Some assumptions for the budgeting were set as follows:

- Expenditures in our (fictitious) budgets are labor and financial costs, which are chosen in ranges of euros; $(+-)$ is between EUR 0 and 50, (+) EUR 50-250, (++) EUR 250-750, and ( +++ ) above EUR 750.

- Related research budget components like field personnel, transportation to the site, meals, and accommodation were not considered. 
- A researcher was categorized as unpaid labor in the research area, since s/he receives salary from the researcher's institution. Thus, the researcher's expenses were ignored.

- Shipping cost of devices and samples, taxes of research devices, and research permit costs were excluded.

- There were no subsidies from research institutions for measurements devices or models.

- None of the scenarios took into account decisions made for a particular intervention and its development.

For scenarios 2 and 3, the end results of possible field campaigns and analysis were discussed with ten experts from different Dutch institutions, who were selected from the working environment of the author. Each scenario had its own specific hydrological objective that fits to an expertise (i.e., hydrogeology, hydrology, remote sensing), but the experts had different hydrological backgrounds. The implemented research with the results and proposed scenarios of several field campaigns were explained to the experts to clarify the content and objective of the research. Subsequently, they had to grade the scenarios based on the level of additional understanding (if any) that would be achieved. The required budget itself was not mentioned to allow experts to objectively value the proposal without any economic consideration. The author picked the Dutch grading scale as follows:

$-1-5.5=$ little understanding of the relevant mechanism of intervention

- 6-7.5 = good understanding of the dominant mechanism of intervention

$-8-8.5=$ better understanding of the dominant mechanism of intervention

- 9-10= complete (full process) understanding of the mechanisms relevant for the intervention

In the interview following the assessment of the scenarios, the experts were also given the opportunity to provide their own alternative approaches that could result in better understanding.

Even though this was a theoretical exercise and that it was not easy to provide clear-cut evidence for the scenarios to be realistic enough, results are useful. There may be many other options of optimization, such as cheaper measurement devices and modeling. Different research institutions prefer different measurement devices, or software developed by certain institutions. Research institutions might already own measurement devices and software, and thus do not want to spend money on others. This specific setup is merely an estimation in the context of the three case studies and may well vary from person to person due to people's preference. However, by asking 10 experts for their input and further analyzing their responses over the entire width of the scenarios, a good degree of objectivity, certainty, and reality can be reached, if not in absolute, then at least in comparative terms. Our results are given in Fig. 5. We discuss the Vietnam case in more detail.

\section{Vietnam case: research budget scenarios and experts' opinions}

To have sufficient understanding of groundwater recharge during the actual research, the expenses of the research budget were reduced to about $60 \%$ (see Table A1). Rainfall measurement is a must since it is used for the input of the model. The hydraulic properties of soil and infiltration tests are important as well. The water level measurement is required to get the ponding in the trench correctly. These costs are not much compared to other measurements. Soil moisture measurement is removed from the field campaign since it is not only expensive but also the access tubes are prone to being taken away by the local people. Isotope tracers are excluded, because the constructed observation wells were not suitable for groundwater sampling. In addition, the cost for this analysis is considered to be expensive. On the other hand, isotopes are beneficial and will provide signals as long as the observation wells would be better constructed. A minimum of three observation wells are set, since it is the minimum or triangle layout to get an idea on the groundwater flow direction. A short but sufficient period of measurements would be during the wet season, where the trench may be filled with rain water.

Even though the cost reduction is significant, the conditions to apply these methods could remain uncertain. For example, when a researcher made a plan for scheduling the starting point of measurement at the beginning of a wet season, no one would expect at first that negotiating with the local community was difficult, even though this determines whether or not the intervention can be built or continued. There has to be willingness from the community to provide land for the intervention. After several discussions and meetings, a local-to-local approach was needed to convince stakeholders that the intervention would be beneficial to the local community. However, no one could predict when and where it could be realized. If the decision to be made for construction was delayed, the plan for hydrological measurements would have to wait until the next wet season, which would have been 1 year later. And if there is a tension to install the measurement devices for an analysis of "with and without", the location of the intervention might shift in time. Thus, new measurement setups have to be adjusted. These conditions will result in loss of data and time for the hydrological research. As such, the minimum budget is somewhat artificial. Conversely, the big difference between the minimum budget and the actual budget suggests that in the Vietnam case, negotiations on the intervention brought along high costs. 

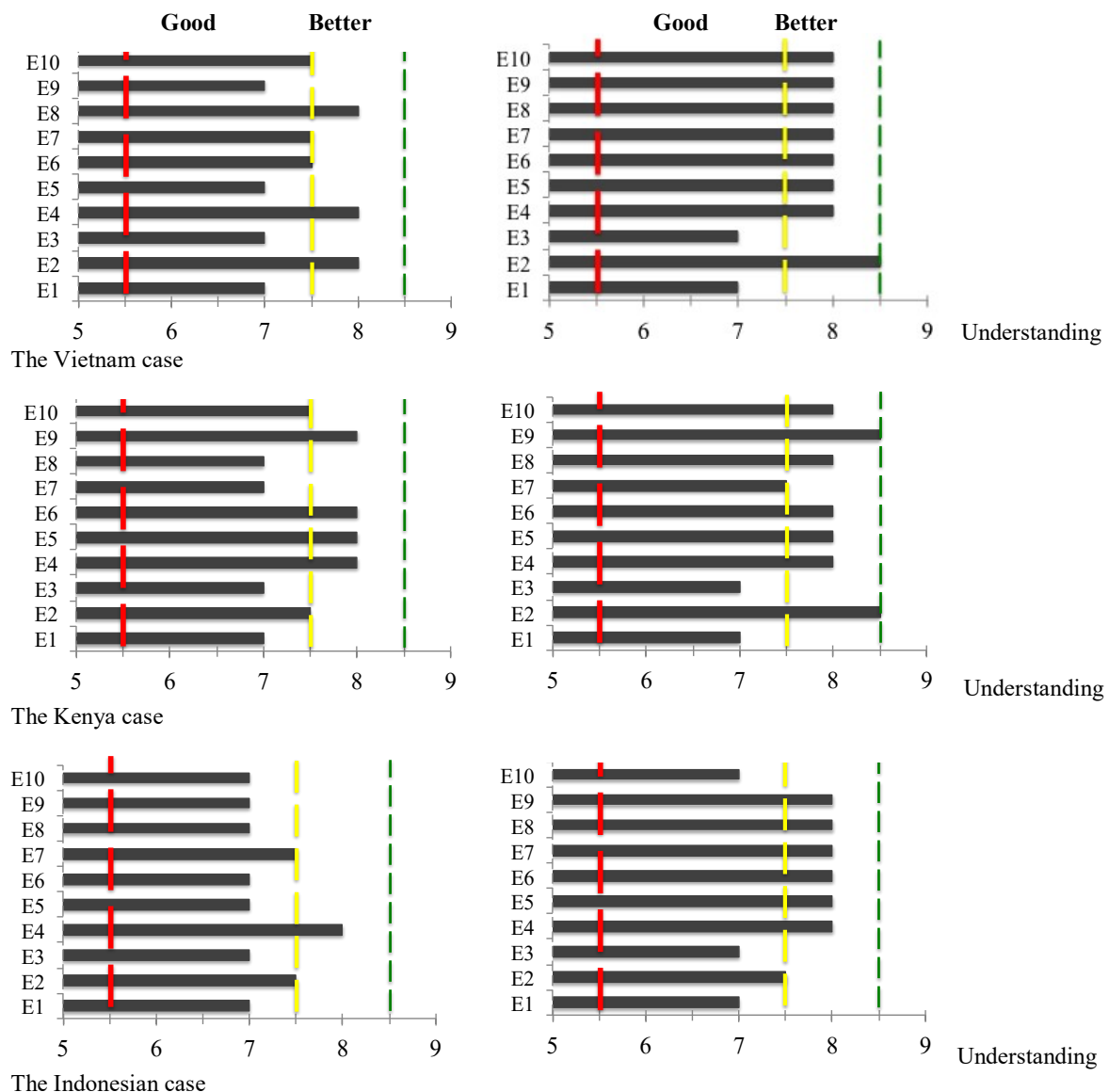

Red dash line $=$ grade 5.5 Yellow dash line $=$ grade 7.5 Green dash line $=$ grade 8.5 $\mathrm{E}=$ expert

Figure 5. Summary of three cases; on the left: scenario 2, right: scenario 3 .

When more budget would be available, scenario 2 (see Table B2) could expand the implemented program by constructing one new observation well and its groundwater level measurements. Also, the sampling period for isotope tracer is extended. The observation well should be placed in line with the existing wells and its screen should be along the pipe, from near soil surface to the bedrock. It would be expected that the recharge can be more apparent where the signal of infiltrated rainwater can directly infiltrate into the pipe. Thus, the groundwater fluctuation and sampling can confirm the result of the implemented research.

In scenario 3 (see Table B3), an $80 \%$ increased budget gives options for more applications and/or more advanced methods. Besides one new observation well and isotope samplings, three other wells should be constructed. The observation wells should be placed at the small trench area. A possible advanced measurement is by performing an electrical resistance tomography (ERT) survey for subsurface imaging. Several cross sections of the subsurface could be ob- tained during the dry and wet period. By having these new wells combined with the analyzed ERT data, the hypotheses could be made more pronounced regarding the difference in groundwater behavior with and without the intervention structure.

The results of the interviews with the experts can be seen in Tables B1-B3. Of the three cases, the Vietnam case had most options, due to better financial conditions, compared than the other two cases. Considering scenario 2, $70 \%$ of the experts believe an additional well and a 1-year continuation of the groundwater level measurements, including isotope samplings and analysis, would result in similar data collection as in the implemented research. One expert considered that extra data might even lead to confusion. Another period of 1-year data could be used for validation, and thus might give more confidence. A very long data series, from 2 to about 10 years of groundwater level measurement would be very beneficial for better understanding the mechanism of the recharge. 
In scenario 3, with an $80 \%$ increase in budget, the value of measurements points to similar results as in scenario 2, with some additional elements. A total of $80 \%$ of the experts say that ERT measurements could increase the understanding of mechanism of the recharge and provide more explanation of the disconnected groundwater system. Thus, it could potentially confirm the groundwater profile and the groundwater level during recharge. Performing ERT either during dry or wet seasons sometimes yields results hard to interpret, since ERT is a static measurement.

In summary, a research plan with $20 \%$ increased funding (scenario 2) appears to obtain similar understanding as the reference result. On the other hand, an $80 \%$ increase in funding may be capable of gaining a better understanding. A costly research plan for a small-scale intervention project may not be economically feasible and thus impossible to implement.

\section{Towards systematic planning}

Despite all the problems we encountered in the three field research projects, we could develop a good understanding of the hydrological impacts of interventions in three different developing countries. In Vietnam, during the wet season, contour trenches contribute to recharge, but only for shortterm impact, up to 2 months. In Kenya, vegetation growth in the trench area as reflected in the signal of greenness index was most likely due to the wet season, without a clear longterm effect from the trenches. In Indonesia, the potential of micro-hydro capacity on the Maluku Islands ranges from 6 to $40 \mathrm{~kW}$. In the three cases, local people participated during the implementation of the projects, both in the intervention and hydrological research. As a result, the field campaigns were not perfect in terms of hydrological standards. Measurement devices were damaged, removed, disappeared, or not located at the final intervention. In the end, we ended up with less data or data of lower quality. Local participation and financial constraints forced us to deal with research and intervention as interacting with and affecting each other.

As this setting is not unique to our three small cases, balancing intervention and research is a general challenge. Tracing back the social reality and the way it shapes intervention and research with the associated budget allowed us to gain more insight into trade-offs between hydrological knowledge and hydrological research management. Based on our experiences, we propose that planning ahead is possible. We propose a new systematic perspective on how to prepare hydrological research for a more effective way to implement small-scale water intervention research initiatives. Being prepared for and responsive to surprises due to human actions can be achieved by developing scenarios that combine hydrological issues with cost-benefit analysis: in a process similar to RAND studies, providing guidance for an approach that anticipates known surprises (Dewar, 2002). In planning for

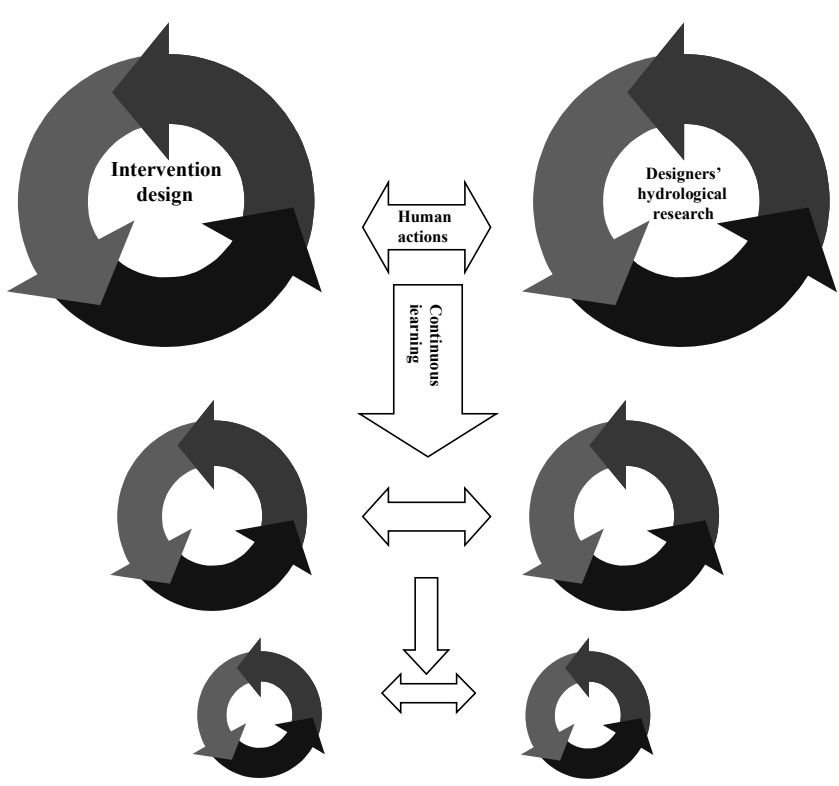

Figure 6. Designing hydrological field research in small-scale intervention (modified from Ertsen, 2002, and Scheer, 1996).

surprises, as outcomes of local negotiations are not known before, considering financial costs and specific research objectives of small-scale interventions, options for field campaigns and analysis that could answer the research questions can then be defined.

Similar to balancing development and conservation (Garnett et al., 2007), when financial constraints - and usually time as well - become important, a researcher should be able to balance what he/she can and cannot do. Since budgets and time for a small-scale intervention are limited, research should be well planned. In order to include the costs of performing hydrological studies and the efficiency (effectiveness) in planning for surprises, we discussed an approach applying cost-benefit analysis. Despite its simplicity, it appears to be a good way to quantify research efforts vs. the (probable) outcomes.

The judgments of the outcomes were obtained from interviews with water experts. Sharing options with other experts adds value to the preparation. Each scholar has their own preferences, and thus there is no single solution. This was shown during the interviews with the experts, when they were forced to make a choice by pushing their preference in grading the available field campaign options. Eventually, even when incorporating experts' inputs, we will still have to make decisions and will possibly select our own preferred choices. In the end, dealing with the local constraints is a decision to be made by the researcher. However, by doing the two analyses of scenarios and cost benefits continuously during planning and performing hydrological research, one will be better informed to make decisions. 
The notion that the effects of human actions to be expected in hydrological field campaign are basically unspecified does not imply that they could not adequately and fruitfully be translated in specific planning, as we have shown. Taking into account human actions in planning field campaigns for something that is usually seen as a single scientific activity implies that each field design should be tuned to the situation under consideration. A designer cannot come up with a standard solution and may experience different stages of learning processes that continue to shape both intervention and hydrological research (see Fig. 6). Paradoxically, introducing such a multifaceted approach asks for hydrological researchers with higher qualifications. Planned improvisation needs scientific expertise, as much as it requires a specific attitude. 


\section{Appendix A: Research budget scenarios}

Table A1. Vietnam Case, scenario 1: to measure rainfall and groundwater level for a short period.

\begin{tabular}{lllllll}
\hline Parameter & Method & Number/samples & Labor & In EUR & Cost & In EUR \\
\hline Rainfall & Tipping bucket & 2 & +- & 40 & +++ & 2015 \\
Soil physics & Lab analysis & 6 & +- & & + & 238 \\
Infiltration capacity & Inversed auger test & 8 & +- & & + & 75 \\
Water level & Meter height reading & 13 & + & 720 & +- & 15 \\
Groundwater level & Observation well and diver & 3 & ++ & & +++ & 5533 \\
& (reached bedrock) & & & & & \\
\hline
\end{tabular}

Notes: $(+-)=$ EUR 0-50, $(+)=$ EUR 50-250, $(++)=$ EUR 250-750, $(+++)$ above EUR 750.

Table A2. Vietnam Case, scenario 2: to recheck the signal of recharge.

\begin{tabular}{|c|c|c|c|c|c|c|}
\hline Parameter & Method & Number/samples & Labor & In EUR & Cost & In EUR \\
\hline Rainfall & Tipping bucket & 2 & +- & 40 & +++ & 2015 \\
\hline Soil moisture & TDR (with access tubes) & 8 & +++ & 2160 & +++ & 4717 \\
\hline Vertical flow path & Dye tracer & 3 & +- & & +- & 10 \\
\hline Soil physics & Lab analysis & 6 & +- & & + & 238 \\
\hline Infiltration capacity & Inversed auger test & 8 & +- & & + & 75 \\
\hline Water level & Meter height reading & 13 & +- & & +- & 15 \\
\hline Groundwater level & $\begin{array}{l}\text { Observation well \& diver } \\
\text { (reached bedrock) }\end{array}$ & $7+1$ & ++ & & +++ & 13893 \\
\hline \multirow[t]{2}{*}{ Isotope tracer } & Lab analysis & $116+116$ & + & & +++ & 1856 \\
\hline & & & Total I & 2200 & Total II & 22819 \\
\hline
\end{tabular}

Notes: $(+-)=$ EUR 0-50, $(+)=$ EUR 50-250, $(++)=$ EUR 250-750, $(+++)$ above EUR 750.

Table A3. Vietnam Case, scenario 3: to map the subsurface.

\begin{tabular}{|c|c|c|c|c|c|c|}
\hline Parameter & Method & Number/samples & Labor & In EUR & Cost & In EUR \\
\hline Rainfall & Tipping bucket & 2 & +- & 40 & +++ & 2015 \\
\hline Soil moisture & TDR (with access tubes) & 8 & +++ & 2160 & +++ & 4717 \\
\hline Vertical flow path & Dye tracer & 3 & +- & & +- & 10 \\
\hline Soil physics & Lab analysis & 6 & +- & & + & 238 \\
\hline Infiltration capacity & Inversed auger test & 8 & +- & & + & 75 \\
\hline Water level & Meter height reading & 13 & +- & & +- & 15 \\
\hline Groundwater level & $\begin{array}{l}\text { Observation well \& diver } \\
\text { (reached bedrock) }\end{array}$ & $7+4$ & + & & +++ & 18909 \\
\hline Isotope tracer & Lab analysis & $116+116$ & + & & +++ & 928 \\
\hline \multirow[t]{2}{*}{ Subsurface mapping } & ERT & 4 & & 2000 & +++ & 10000 \\
\hline & & & Total I & 4200 & Total II & 36907 \\
\hline
\end{tabular}

Notes: $(+-)=$ EUR 0-50, $(+)=$ EUR 50-250, $(++)=$ EUR 250-750, $(+++)$ above EUR 750. 
Table A4. Kenya case, scenario 1: to use remote sensing data.

\begin{tabular}{lllllll}
\hline Parameter & Method & Number/samples & Labor & In EUR & Cost & In EUR \\
\hline Rainfall & Tipping bucket & 2 & + & 120 & +++ & 1305 \\
& Remote sensing analysis & - & & - & \\
Greenness index & Remote sensing analysis & - & & - & \\
\hline & & Total I & 120 & Total II & 1305 \\
\hline
\end{tabular}

Notes: $(+-)=$ EUR 0-50, $(+)=$ EUR 50-250, $(++)=$ EUR 250-750, $(+++)$ above EUR 750.

Table A5. Kenya case, scenario 2: to retry 1-year soil moisture measurement.

\begin{tabular}{lllllll}
\hline Parameter & Method & Number/samples & Labor & In EUR & Cost & In EUR \\
\hline Rainfall & Tipping bucket & 2 & + & 120 & +++ & 1305 \\
& Remote sensing analysis & & - & & - & \\
Soil moisture & TDR (with access tubes) & 6 & +++ & 2880 & +++ & 4990 \\
Soil physics & Lab analysis & 8 & +- & 40 & +- & \\
Greenness index & Remote sensing analysis & - & & - & & \\
Erosion and sedimentation & Cs analysis & 128 & + & 100 & +++ & 1699 \\
\hline & & & Total I & 3140 & Total II & 7994 \\
\hline
\end{tabular}

Notes: $(+-)=$ EUR 0-50, $(+)=$ EUR 50-250, $(++)=$ EUR 250-750, $(+++)$ above EUR 750.

Table A6. Kenya Case, scenario 3: to maximize remote sensing analysis.

\begin{tabular}{|c|c|c|c|c|c|c|}
\hline Parameter & Method & Number/samples & Labor & In EUR & Cost & In EUR \\
\hline Rainfall & $\begin{array}{l}\text { Tipping bucket } \\
\text { Remote sensing analysis }\end{array}$ & 2 & $\begin{array}{l}+ \\
-\end{array}$ & 120 & $\begin{array}{l}+++ \\
-\end{array}$ & 1305 \\
\hline Soil moisture & TDR (with access tubes) & 6 & +++ & 2880 & +++ & 4990 \\
\hline Soil physics & Lab analysis & 8 & + & 40 & +- & \\
\hline Greenness index & Remote sensing analysis & - & & - & & \\
\hline Erosion and sedimentation & Cs analysis & 128 & + & 100 & +++ & 1699 \\
\hline \multirow[t]{2}{*}{ High-resolution greenness index } & Remote sensing analysis & - & & +++ & 8400 & \\
\hline & & & Total I & 3140 & Total II & 16394 \\
\hline
\end{tabular}

Notes: $(+-)=$ EUR $0-50,(+)=$ EUR 50-250, $(++)=$ EUR 250-750, $(+++)$ above EUR 750

Table A7. Indonesia case, scenario 1: to measure discharge of one river for 1 year.

\begin{tabular}{lllllll}
\hline Parameter & Method & Number/samples & Labor & In EUR & Cost & In EUR \\
\hline Discharge & Velocity area (diver) & 3 & +- & & +++ & 1500 \\
& Dilution gauging & & +- & & +- & 25 \\
\multirow{2}{*}{ Head } & Remote sensing analysis & - & & - & & \\
\hline & & & Total I & 50 & Total II & 1525 \\
\hline
\end{tabular}

Notes: $(+-)=$ EUR 0-50, $(+)=$ EUR 50-250, $(++)=$ EUR 250-750, $(+++)$ above EUR 750. 
Table A8. Indonesia case, scenario 2: to investigate discharge of another river.

\begin{tabular}{lllllll}
\hline Parameter & Method & Number/samples & Labor & In EUR & Cost & In EUR \\
\hline Rainfall & Tipping bucket & 2 & +- & 50 & +++ & 1990 \\
Discharge & Velocity area (diver) & $3+2$ & +- & & +++ & 2500 \\
& Dilution gauging & & +- & & +- & 25 \\
Head & Remote sensing analysis & - & & - & & \\
\hline & & & Total I & 50 & Total II & 4515 \\
\hline
\end{tabular}

Notes: $(+-)=$ EUR 0-50, $(+)=$ EUR 50-250, $(++)=$ EUR 250-750, $(+++)$ above EUR 750.

Table A9. Indonesia case, scenario 3: to investigate discharges of four other rivers.

\begin{tabular}{lllllll}
\hline Parameter & Method & Number/samples & Labor & In EUR & Cost & In EUR \\
\hline Rainfall & Tipping bucket & 2 & +- & 50 & +++ & 1990 \\
\hline Discharge & Velocity area (diver) & $3+8$ & +- & & +++ & 5500 \\
\hline \multirow{2}{*}{ Head } & Dilution gauging & Remote sensing analysis & - & +- & & +- \\
\hline
\end{tabular}

Notes: $(+-)=$ EUR $0-50,(+)=$ EUR 50-250, $(++)=$ EUR 250-750, $(+++)$ above EUR 750. 


\section{Appendix B: The experts' opinions}

Table B1. Vietnam case: the experts' opinions.

\begin{tabular}{|c|c|c|c|c|c|c|c|}
\hline \multirow{2}{*}{ No } & \multirow{2}{*}{ Title } & \multirow{2}{*}{ Institution } & \multicolumn{2}{|r|}{ Scenario 2} & \multicolumn{2}{|r|}{ Scenario 3} & \multirow{2}{*}{$\begin{array}{l}\text { Other suggestions } \\
\text { Remarks }\end{array}$} \\
\hline & & & Grade & Remarks & Grade & Remarks & \\
\hline 1 & $\mathrm{PhD}$ & Utrecht University & 7 & $\begin{array}{l}\text { Seasonality is already } \\
\text { included }\end{array}$ & 7 & $\begin{array}{l}\text { Disadvantage: profiles } \\
\text { measured only one time }\end{array}$ & $\begin{array}{l}\text { Require } 10 \text {-year groundwater } \\
\text { level data }\end{array}$ \\
\hline 2 & MSc & Delft University & 8 & Measure for at least 2 years & 8.5 & $\begin{array}{l}\text { Model only tests } \\
\text { hypothesis. Measurements al- } \\
\text { ready answered the research } \\
\text { question }\end{array}$ & - \\
\hline 3 & MSc & Delft University & 7 & $\begin{array}{l}\text { Isotope is an advance method } \\
\text { with good result }\end{array}$ & 7 & $\begin{array}{l}\text { One-time measurement equals } \\
\text { to nothing }\end{array}$ & $\begin{array}{l}\text { To study the unsaturated zone, } \\
\text { to measure rate of recharge us- } \\
\text { ing SM sensors, etc. }\end{array}$ \\
\hline 4 & $\mathrm{PhD}$ & Delft University & 8 & $\begin{array}{l}\text { Need validation and try to get } \\
\text { more confidence or to decrease } \\
\text { uncertainty. But it could even } \\
\text { lead to confusing results }\end{array}$ & 8 & Hard to interpret & $\begin{array}{l}\text { Depending on Ks and soil } \\
\text { moisture. Challenging (quali- } \\
\text { tative result): infiltration test } \\
\text { and surface water measure- } \\
\text { ments }\end{array}$ \\
\hline 5 & $\mathrm{PhD}$ & Delft University & 7 & Skeptical & 8 & - & - \\
\hline 6 & Prof & UNESCO-IHE & 7.5 & - & 8 & - & - \\
\hline 7 & $\mathrm{PhD}$ & UNESCO-IHE & 7.5 & - & 8 & $\begin{array}{l}\text { Increase resistivity of water by } \\
\text { injecting sodium chloride }\end{array}$ & $\begin{array}{l}\text { More artificial tracer, (yellow } \\
\text { dye), soil moisture measure- } \\
\text { ment below the trench (use } \\
\text { cheap sensors like Decagon). } \\
\text { A need of timely scale me- } \\
\text { surements or time-lapse mea- } \\
\text { surements }\end{array}$ \\
\hline 8 & $\mathrm{PhD}$ & Delft University & 8 & - & 8 & - & $\begin{array}{l}\text { Previous measurements were } \\
\text { already sufficient }\end{array}$ \\
\hline 9 & MSc & Eindhoven-Deltares & 7 & - & 8 & - & $\begin{array}{l}\text { It would be an advantage to } \\
\text { have } 3-D\end{array}$ \\
\hline 10 & $\mathrm{PhD}$ & Delft University & 7.5 & - & 8 & $\begin{array}{l}\text { Expensive (cost } \\
\text { magnitude about EUR } 10000 \text { - } \\
30000 \text { for a } 5 \mathrm{~m} \text { interval) }\end{array}$ & $\begin{array}{l}\text { Geophysical approach for spa- } \\
\text { tial information. Soil type } \\
\text { analysis, ground radar method, } \\
\text { and } 1-2 \text { points tracer (pollu- } \\
\text { tion) }\end{array}$ \\
\hline
\end{tabular}


Table B2. Kenya case: the experts' opinions.

\begin{tabular}{|c|c|c|c|c|c|c|c|}
\hline \multirow{2}{*}{ No } & \multirow{2}{*}{ Title } & \multirow{2}{*}{ Institution } & \multicolumn{2}{|r|}{ Scenario 2} & \multicolumn{2}{|r|}{ Scenario 3} & \multirow{2}{*}{$\begin{array}{l}\text { Other suggestions } \\
\text { Remarks }\end{array}$} \\
\hline & & & Grade & Remarks & Grade & Remarks & \\
\hline 1 & $\mathrm{PhD}$ & Utrecht University & 7 & $\begin{array}{l}\text { NDVI related to temperature, } \\
\text { LAI, but does not correlate } \\
\text { to soil moisture }\end{array}$ & 7 & - & $\begin{array}{l}\text { Try FPAR (fractional photosynthetically } \\
\text { active radiation) }\end{array}$ \\
\hline 2 & $\mathrm{MSc}$ & Delft University & 7.5 & - & 8.5 & - & $\begin{array}{l}\text { Soil temperature measurement to estimate } \\
\text { evaporation }\end{array}$ \\
\hline 3 & MSc & Delft University & 7 & Enough & 7 & Enough & - \\
\hline 4 & $\mathrm{PhD}$ & Delft University & 8 & - & 8 & - & $\begin{array}{l}\text { Aerial photos, LAI (although it is } \\
\text { difficult) }\end{array}$ \\
\hline 5 & $\mathrm{PhD}$ & Delft University & 8 & - & 8 & - & $\begin{array}{l}\text { Try to measure discharge, modeling } \\
\text { the impact of soil moisture } \\
\text { and transpiration }\end{array}$ \\
\hline 6 & Prof & UNESCO-IHE & 8 & - & 8 & - & $\begin{array}{l}\text { Discharge measurements (notches) to } \\
\text { close the detail water balance, } \\
\text { microstation especially evaporation }\end{array}$ \\
\hline 7 & $\mathrm{PhD}$ & UNESCO-IHE & 7 & - & 7.5 & - & $\begin{array}{l}\text { Plant's physiological effects } \\
\text { like water stress }\end{array}$ \\
\hline 8 & MSc & Delft University & 7 & - & 8 & - & A higher resolution is usually better \\
\hline 9 & MSc & Eindhoven-Deltares & 8 & - & 8.5 & - & - \\
\hline 10 & $\mathrm{PhD}$ & Delft University & 7.5 & - & 8 & Try to see sub-pixel & $\begin{array}{l}\text { Pixel variability (to minimize the interval } \\
\text { of images). Sensors for spectrometer } \\
\text { through cable trolley/station and } \\
\text { aerial photos (for more detail images) }\end{array}$ \\
\hline
\end{tabular}


Table B3. Indonesia case: the experts' opinions.

\begin{tabular}{|c|c|c|c|c|c|c|c|}
\hline \multirow{2}{*}{ No } & \multirow{2}{*}{ Title } & \multirow{2}{*}{ Institution } & \multicolumn{2}{|r|}{ Scenario 2} & \multicolumn{2}{|r|}{ Scenario 3} & \multirow{2}{*}{$\begin{array}{l}\text { Other suggestions } \\
\text { Remarks }\end{array}$} \\
\hline & & & Grade & Remarks & Grade & Remarks & \\
\hline 1 & $\mathrm{PhD}$ & Utrecht University & 7 & Absolute value is enough & 7 & - & - \\
\hline 2 & $\mathrm{MSc}$ & Delft University & 7.5 & $\begin{array}{l}\text { Reach a statistical } \\
\text { information of regime }\end{array}$ & 7.5 & $\begin{array}{l}\text { Reach a statistical } \\
\text { information of regime }\end{array}$ & - \\
\hline 3 & MSc & Delft University & 7 & - & 7 & - & - \\
\hline 4 & $\mathrm{PhD}$ & Delft University & 8 & $\begin{array}{l}\text { With more data we can get } \\
\text { new or not increased under- } \\
\text { standing }\end{array}$ & 8 & $\begin{array}{l}\text { Spatial information is } \\
\text { important }\end{array}$ & $\begin{array}{l}\text { Integrate geology and other } \\
\text { point measurements at other } \\
\text { rivers }\end{array}$ \\
\hline 5 & $\mathrm{PhD}$ & Delft University & 7 & Hydrology engineering & 8 & $\begin{array}{l}\text { Measure at more various areas. } \\
\text { Start by investigating maps of } \\
\text { the different factors; geologi- } \\
\text { cal, topographical, vegetation, } \\
\text { and boundary condition }\end{array}$ & $\begin{array}{l}\text { More variability means more } \\
\text { recommendation to result in a } \\
\text { catchment classification with } \\
\text { certain discharges, but maybe } \\
\text { diverse catchments are de- } \\
\text { pended only on landscape and } \\
\text { geology }\end{array}$ \\
\hline 6 & Prof & UNESCO-IHE & 7 & - & 8 & - & Higher resolution of DEM. \\
\hline 7 & $\mathrm{PhD}$ & UNESCO-IHE & 7.5 & - & 8 & - & $\begin{array}{l}\text { Maps or information on inter- } \\
\text { net: meteorological data (rain- } \\
\text { fall and temperature) DEM, } \\
\text { soil, geology, and land use. } \\
\text { Multiple regression }(Q)\end{array}$ \\
\hline 8 & $\mathrm{PhD}$ & Delft University & 7 & - & 8 & - & $\begin{array}{l}\text { Map of the basin. Field survey } \\
\text { on all potential places based } \\
\text { on the distance from the vil- } \\
\text { lage, etc. Socioeconomic stud- } \\
\text { ies to answer where to build a } \\
\text { MHPP }\end{array}$ \\
\hline 9 & $\mathrm{MSc}$ & Eindhoven-Deltares & 7 & - & 8 & - & Geology and land use map. \\
\hline 10 & $\mathrm{PhD}$ & Delft University & 7 & - & 7 & - & $\begin{array}{l}\text { Not important in hydrological } \\
\text { science, but just as hydrologi- } \\
\text { cal measurement. If one goes } \\
\text { for uncertainty, then a long } \\
\text { time series is needed. A flume } \\
\text { (which will be costly) is an op- } \\
\text { tion to measure the } Q\end{array}$ \\
\hline
\end{tabular}


Acknowledgements. The authors would like to thank the funding agencies and key people for their support in each of the three small-scale water projects; Royal Haskoning Vietnam; Marieke Nieuwaal; and local partners, both from the community and the Vietnamese government; International Foundation for Science, Sweden; Cox Sitters (Moi University, Kenya); Jeannis-Nicos Leist (University of Göttingen); the Dutch Ministry of Economic Affairs, Agriculture, and Innovation; and the project consortium (Noes Tuankotta, UKIM and IBEKA). We also would like to thank the local people who helped us in the field for technical and logistic assistance, but are not mentioned here. Lastly, we thank the 10 water experts for their participation in the interviews.

Edited by: S. Thompson

Reviewed by: two anonymous referees

\section{References}

Arnstein, S. R.: A Ladder of Citizen Participation, J. Am. Inst. Plann., 35, 216-224, 1969.

Baiocchi, D. and Fox, D. S.: Surprise! From CEOs to Navy SEALs: How a Select Group of Professionals Prepare for and Respond to the Unexpected, Santa Monica, CA, RAND Corporation, available at: http://www.rand.org/pubs/research_reports/RR341.html, 2013.

Beratan, K. K.: Summary: addressing the interactional challenges of moving collaborative adaptive management from theory to practice, Ecol. Soc., 19, 46, doi:10.5751/ES-06399-190146, 2014.

Blume, T., Zehe, E., Reusser, D. E., Iroume, A., and Bronstert, A.: Investigation of runoff generation in a pristine, poorly gauged catchment in the Chilean Andes I: A multimethod experimental study, Hydrol. Process., 22, 3661-3675, doi:10.1002/hyp.6971, 2008.

Choguill, M. B. G.: A Ladder of Community Participation for Underdeveloped Countries, Habitat Int., 20, 431-444, 1996.

Cleaver, F.: Paradoxes of participation: questioning participatory approaches to development, J. Int. Develop., 11, p. 597, 1999.

Daniell, K. A., White, I., Ferrand, N., Ribarova, I. S., Coad, P., Rougier, J.-E., Hare, M., Jones, N. A., Popova, A., Rollin, D., Perez, P., and Burn, S.: Co-engineering participatory water management processes: theory and insights from Australian and Bulgarian interventions, Ecol. Soc., 15, 11, available at: http://www.ecologyandsociety.org/vol15/iss4/art11/ (last access: 20 May 2014), 2010.

Dewar. J. A: Assumption-based Planning, A Tool for Reducing Avoidable Surprises, RAND, Cambridge University Press, Cambridge, 248 pp., 2002.

Dewar, J. A., Builder, C. H., Hix, W. M., and Levin, M. H.: Assumption-based planning; A Planning Tool for Very Uncertain Times, RAND CORP Santa Monica, CA, 78 pp., 1993.

Doty, R. D.: Soil water distribution on a contour-trenched area, US Department of Agriculture Forest Service, Research Note INT163, 6 pp., 1972.

ECSP: Water Stories: Expanding Opportunities in Small-scale water and sanitation projects, Report from the Navigating Peace Initiative of the Environmental Change and Security Program, Woodrow Wilson International Center for Scholars, Washington, 89 pp., 2006.
Ertsen, M. W.: The technical and the social in engineering education, in: Design and the social sciences, Making connections, edited by: Frascara J., Taylor and Francis, London, 146-157, 2002.

Ertsen, M. W. and Hut, R.: Two waterfalls do not hear each other. Sand-storage dams, science and sustainable development in Kenya, Phys. Chem.-Earth, 34, 14-22, 2009.

Ertsen, M. W., Biesbrouck, B., Postma, L., and van Westerop, M.: Participatory design of sand storage dams, edited by: Goessling, T., Jansen, R. J. G., and Oerlemans, L. A. G., 2005 Coalitions and Collisions, Wolf Publishers, Nijmegen, 175-185, 2005.

Fabricius, C. and Cundill, G.:. Learning in adaptive management: insights from published practice. Ecol. Soc., 19, 29, doi:10.5751/ES-06263-190129, 2014.

Falkenmark, M., Fox, P., Persson, G., and Rockström, J.: Water harvesting for upgrading of rainfed agriculture, Problem analysis and research needs, Stockholm International Water Institute, 87 pp., 2001.

Farrington, J, Turton, C., and James, A. J.: Participatory watershed development, Challenges for the twenty-first century, Oxford, Oxford University Press, 382 pp., 1999.

Garnett, S. T., Sayer, J., and Du Toit, J.: Improving the effectiveness of interventions to balance conservation and development: a conceptual framework. Ecol. Soc., 12, 2, http: //www.ecologyandsociety.org/vol12/iss1/art2/ (last access: 20 May 2014), 2007.

Gomani. M. C., Mahay, F., Mbilinyi, B., Dietrich, O., and Lischeid, G.: Establishment of a hydrological monitoring system through a participatory approach in a small tropical catchment in Tanzania: Learning hydrology from the local people. Proceedings of the Conference on International Research on Food Security, Natural Resource Management and Rural Development, 6-8 October 2009, University of Hamburg, 4 pp., 2009.

Govardhan Das, S. V. and Rao, P. S.: Participatory Hydrological Monitoring (PHM) - An effective tool for community managed groundwater systems, in: Proceedings of the National conference on land resource management for food, employment and environmental security, Soil Conservation Society of India, 557-565, 2000.

Govardhan Das, S. V.: Judicious Management of Groundwater through Participatory Hydrological Monitoring: A Manual, Arcadis EuroConsult, Arnhem, the Netherlands, available at: http://www.groundwatermanagement.org/documents/ manualpcphydrologicalmonitoring.pdf (last access: 30 June 2014), 2003.

Hagen, D. and Evju, M.: Using short-term monitoring data to achieve goals in a large-scale restoration. Ecol. Soc., 18, 29, doi:10.5751/ES-05769-180329, 2013.

Hamilton S.: Completing the loop: from data to decisions and back to data,. Hydrol. Process., 21, 3105-3106, 2007.

Hrachowitz, M., Bohte, R., Mul, M. L., Bogaard, T. A., Savenije, H. H. G., and Uhlenbrook, S.: On the value of combined event runoff and tracer analysis to improve understanding of catchment functioning in a data-scarce semi-arid area, Hydrol. Earth Syst. Sci., 15, 2007-2024, doi:10.5194/hess-15-2007-2011, 2011.

Hrachowitz, M., Savenije, H. H. G., Blöschl, G., McDonnell, J. J., Sivapalan, M., Pomeroy, J. W., Arheimer, B., Blume, T., Clark, M. P., Ehret, U., Fenicia, F., Freer, J. E., Gelfan, A., Gupta, H. V., Hughes, D. A., Hut, R. W., Montanari, A., Pande, S., Tetzlaff, 
D., Troch, P. A., Uhlenbrook, S., Wagener, T., Winsemius, H. C., Woods, R. A., Zehe, E., and Cudennec, C.: A decade of Predictions in Ungauged Basins (PUB) - a review, Hydrol. Sci. J., 58, 1198-1255, doi:10.1080/02626667.2013.803183, 2013.

IAP2 (International Association for Public Participation), IAP2 home page, http://www.iap2.org (last access: 17 April 2014), 2007.

Karjalainen, T. P., Rossi, P. M., Ala-aho, P., Eskelinen, R., Reinikainen, K., Kløve, B., Pulido-Velazquez, M., and Yang, H.: A decision analysis framework for stakeholder involvement and learning in groundwater management, Hydrol. Earth Syst. Sci., 17, 5141-5153, doi:10.5194/hess-17-5141-2013, 2013.

Kongo, V. M., Kosgei, J. R., Jewitt, G. P. W., and Lorentz, S. A.: Establishment of a catchment monitoring network through a participatory approach in a rural community in South Africa, Hydrol. Earth Syst. Sci., 14, 2507-2525, doi:10.5194/hess-14-25072010, 2010.

Lane, S. N.: Acting, predicting and intervening in a sociohydrological world, Hydrol. Earth Syst. Sci., 18, 927-952, doi:10.5194/hess-18-927-2014, 2014.

Lasage, R., Aerts, J., Mutiso, G.-C., and De Vries, A.: Potential for community based adaptations to droughts: sand dams in Kitui, Kenya, Phys. Chem. Earth, 33, 67-73, 2008.

Leahy, J. E. and Anderson, D. H.: Trust factors in community-water resource management agency relationships, Landsc. Urban Plan., 87, 100-107, 2008.

Linstone, H. A. and Turoff, M. (Eds.): The Delphi Method: Techniques and Applications, Addison-Wesley, Reading, Massachusetts, 3-12, 1975.

Mackenzie, J., Tan, P.-L., Hoverman, S., and Baldwin, C.: The Value and Limitations of Participatory Action Research Methodology, J. Hydrol., 474, 11-12, 2012.

McGuire, K. and McDonnell, J.: Stable Isotope Tracers in Watershed Hydrology, in: Stable Isotopes in Ecology and Environmental Science, Second Edition, edited by: Michener, R. and Lajtha, K., Blackwell Publishing Ltd, Oxford, UK, 334-365, doi:10.1002/9780470691854.ch11, 2007.

Merz, B., Vorogushyn, S., Lall, U., Viglione, A., and Bloeschl, G.: Charting unknown waters - On the role of surprise in flood risk assessment and management, Water Resour. Res., 51, 63996416, doi:10.1002/2015WR017464, 2015.

Mul, M. L., Savenije, H. H. G., and Uhlenbrook, S.: Spatial rainfall variability and runoff response during an extreme event in a semi-arid catchment in the South Pare Mountains, Tanzania, Hydrol. Earth Syst. Sci., 13, 1659-1670, doi:10.5194/hess-131659-2009, 2009.

Phalla, C. and Paradis, S.: Use of Hydrological Knowledge and Community Participation for Improving Decision-making on Irrigation Water Allocation, Working Paper Series No. 49, A CDRI Publication, 2011.

Poolman M. I.: Present \& Future: Visualising ideas of water infrastructure design. PhD Thesis Delft University of Technology, the Netherlands, 2011.

Porchet, M. and Laferrere, H.: Détermination des caractéristiques hydrodynamiques des sols en place. Mémoire et notes techniques. Annales du Ministère de l'Agriculture, France, 64, 5-68, 1935.

Reed, M. S., Evely, A. C., Cundill, G., Fazey, I., Glass, J., Laing, A., Newig, J., Parrish, B., Prell, C., Raymond, C., and Stringer,
L. C.: What is social learning? Ecol. Soc., 15, r1, http://www. ecologyandsociety.org/vol15/iss4/resp1/, 2010.

Rodela, R., Cundill, G., and Wals, A. E. J.: An analysis of the methodological underpinnings of social learning research in natural resource management, Ecol. Econ., 77, 16-26, 2012.

Rodgers, P., Soulsby, C., Waldron, S., and Tetzlaff, D.: Using stable isotope tracers to assess hydrological flow paths, residence times and landscape influences in a nested mesoscale catchment, Hydrol. Earth Syst. Sci. 9, 139-155, doi:10.5194/hess-9-139-2005, 2005.

Sassone, P. G.: Cost-Benefit Analysis - A Handbook, Academic Press, New York, USA, 190 pp., 1978.

Scheer, S. H.: Communication between irrigation engineers and farmers: the case of project design in North Senegal, PhD thesis, Landbouwuniversiteit Wageningen, 1996.

Šimůnek, J., van Genuchten, M. T., and Šejna, M.: Development and Applications of the HYDRUS and STANMOD Software Packages and Related Codes, Vadose Zone J., 7, 587-600, 2008.

Sivapalan, M., Takeuchi, K., Franks, S. W., Gupta, V. K., Karambiri, H., Lakshmi, V., Liang, X., McDonnell, J. J., Mendiondo, E. M., O'Connell, P. E., Oki, T., Pomeroy, J. W., Schertzer, D., Uhlenbrook, S., and Zehe, E.: IAHS Decade on predictions in ungauged basins (PUB), 2003-2012: Shaping an exciting future for the hydrological sciences, Hydrol. Sci. J., 48, 857-880, 2003.

Sivapalan, M., Konar, M., Srinivasan, V., Chhatre, A., Wutich, A., Scott, C. A., Wescoat, J. L., and RodríguezIturbe, I.: Socio-hydrology: Use-inspired water sustainability science for the Anthropocene, Earth. Future, 2, 225-230, doi:10.1002/2013EF000164, 2014.

Soulsby, C., Neal, C., Laudon, H., Burns, D. A., Merot, P., Bonell, M., Dunn, S. M., and Tetzlaff, D.: Catchment data for process conceptualization: simply not enough?, Hydrol. Process., 22, 2057-2061, 2008.

Srinivasan, L.: Tools for Communication Participation: A Manual for Training Trainers in Participatory Techniques: PROWESS/UNDP-World Bank Water and Sanitation Program, 167 pp., 1990.

Srinivasan, V., Thompson, S., Madhyastha, K., Penny, G., Jeremiah, K., and Lele, S.: Why is the Arkavathy River drying? A multiplehypothesis approach in a data-scarce region, Hydrol. Earth Syst. Sci., 19, 1905-1917, doi:10.5194/hess-19-1905-2015, 2015.

Thompson, S. E., Sivapalan, M., Harman, C. J., Srinivasan, V., Hipsey, M. R., Reed, P., Montanari, A., and Blöschl, G.: Developing predictive insight into changing water systems: useinspired hydrologic science for the Anthropocene, Hydrol. Earth Syst. Sci., 17, 5013-5039, doi:10.5194/hess-17-50132013, 2013.

Van Koppen, B.: Large-Scale and Small-Scale Infrastructure for Growth and Development, International Water Management Institute, Southern Africa Regional Program, Pretoria, South Africa, 12 pp., 2009.

Verbist, K., Cornelis, W. M., Gabriels, D., Alaerts, K., and Soto, G.: Using an inverse modelling approach to evaluate the water retention in a simple water harvesting technique, Hydrol. Earth Syst. Sci., 13, 1979-1992, doi:10.5194/hess-13-1979-2009, 2009.

Vincent, L. F.: Towards a smallholder hydrology for equitable and sustainable water management, Natural Resources Forum, 27, 108-116, doi:10.1111/1477-8947.00046, 2003. 
Von Korff, Y., Daniell, K. A., Moellenkamp, S., Bots, P., and Bijlsma, R. M.: Implementing participatory water management: recent advances in theory, practice, and evaluation, Ecol. Soc., 17, 30, doi:10.5751/ES-04733-170130, 2012.

Warner, D. B. and Abate, C. G.: Guidelines for the Development of Small-Scale Rural Water Supply and Sanitation Projects in East Africa, Catholic Relief Services, Nairobi, Kenya, 51 pp., 2005.
Winsemius, H.: Interactive comment on "HESS Opinions "Urgent water challenges are not sufficiently researched"' by P. van der Zaag et al., Hydrol. Earth Syst. Sci. Discuss., 6, C342-C345, 2009. 